\title{
ПІДСТАВИ ВИНИКНЕННЯ ДОНОРСТВА І ТРАНСПЛАНТАЦІї В УКРАЇНІ
}

\author{
ОЛІйНИК Роман Володимирович - аспірант кафедри цивільного права та \\ процесу юридичного факультету Львівського національного університету імені \\ Івана Франка
}

DOI 10.32782/NP.2021.3.27

\begin{abstract}
Стаття присвячена підставам донорства i трансплантащй в Україні. Виникнення иивільних правовідносини пов'язано із настанням юридичних фбактів - різних життєвих обставин, які створюють певні юридичні наслідки. Однак, не всі життеві обставини стають юридичними фактами. Для изього потрібно, шоб норми ицвільного законодавства пов'язували з ними настання певних правових наслідків. Юридичні фбакти, що є підставою виникнення ијивільних правовідносин стосовно донорства, мають свою специфіку. Пери за все, мова йде про те, що це має бути не один юридичний бакт, а певна їх сукупність. А подруге, такі підстави можна розділити на дві групи: медичні та юридичні.

Ключові слова: анатомічні матеріали; донорство; медичний прачівник; реципієнт; трансплантація.
\end{abstract}

До переліку юридичних фактів, які є підставами виникнення цивільних прав та обов’язків, згідно зі статтею 11 ЦК України, належать:

- договори та інші правочини;

- створення літературних, художніх творів, винаходів та інших результатів інтелектуальної, творчої діяльності;

- завдання майнової (матеріальної) та моральної шкоди іншій особі; інші юридичні факти.

Разом з тим, цей перелік не є вичерпним, оскільки законодавчо неможливо охопити весь спектр діяльності фізичних та юридичних осіб. Таким чином, основною ознакою юридичних фактів $є$ не їх нормативне закріплення в цивільному законодавстві, а спричинення ними правових наслідків.

В окремих випадках настання юридичних наслідків пов'язується не з одним фактом, а з їх сукупністю, тобто так званим юридичним складом.

Юридичний склад моделюється таким чином, що окремі юридичні факти, які до нього входять, можуть виникати незалежно один від одного в будь-якій послідовності. Після появи останнього 3 необхідної сукупності фактів юридичний склад стає завершеним, що викликає виникнення, зміну чи припинення правовідношення (суб'єктивних прав та обов'язків його учасників). Таким чином, тут діє принцип незалежного накопичення елементів складу. При цьому не має значення, який з наведених фактів виник раніше. Важливим 6 результат - наявність усіх фактів у сукупності.

Юридичні факти, що є підставою виникнення цивільних правовідносин стосовно донорства, мають свою специфіку. Перш за все, мова йде про те, що це має бути не один юридичний факт, а певна їх сукупність. А до-друге, такі підстави можна розділити на дві групи: медичні та юридичні.

До групи медичних підстав належать:

- хвороба реципієнта;

- смерть донора (у випадку посмертного донорства);

- сумісність органів або інших анатомічних матеріалів донора та реципієнт; 
- відсутність захворювань у донора, що можуть передаватись при трансплантації.

До юридичних підстав належать:

- надання письмової згоди особи за життя або членів сім’ї після їі смерті;

- у випадку застосування презумпції згоди, відсутність заперечення особи за життя або членів сім’ї після ії смерті[1, C.117-118].

Слід детально висвітлити кожну 3 підстав окремо.

Хвороба реципієнта. Відповідно до статті 13 Закону України «Про застосування трансплантації анатомічних матеріалів людині» трансплантація як метод лікування застосовується виключно за наявності медичних показань за умови неможливості збереження життя або відновлення здоров'я хворого іншими методами лікування, і здійснюється відповідно до галузевих стандартів у сфері охорони здоров'я за згодою об'єктивно поінформованої дієздатної особи (реципієнта), крім випадків, передбачених цим Законом. Неможливість збереження життя або відновлення здоров'я хворого іншими методами лікування та наявність у нього медичних показань для застосування трансплантації встановлюе консиліум лікарів відповідного закладу охорони здоров'я, в якому хворий перебуває на лікуванні чи диспансерному обліку. Таким чином, не будь-яка хвороба особи може виступати юридичним фактом, що є однією з підстав виникнення правовідносин щодо трансплантації. Якщо є можливим застосування інших методів лікування, аніж трансплантація, то така хвороба не породжує відповідні цивільні правовідносини.

Виникнення правовідносин з посмертного донорства у разі смерті донора.

Відповідно до статті 52 Закону України «Основи законодавства України про охорону здоров'я» особа вважається померлою 3 моменту, коли встановлена смерть ії мозку або їі біологічна смерть.

Статтею 17 Закону України «Про застосування трансплантації анатомічних матеріалів людині» передбачено, що вилучення анатомічних матеріалів для трансплантації дозволяється у донора-трупа після підпи- сання акта констатації смерті його головного мозку.

Така позиція піддається критиці лікарями, оскільки смерть організму в медицині розглядається як повільне, а не одночасне припинення життєдіяльності окремих тканин і органів. Вивчення даного процесу потрібне для вирішення проблем посмертного донорства та трансплантації. Разом 3 тим, час відмирання мозку вважається в медицині тим моментом, з настанням якого припиняється процес лікування та, водночас, виникає можливість забору гомо трансплантатів [7, С.316].

Вилучення анатомічних матеріалів для виготовлення біоімплантатів дозволяється у донора-трупа після підписання акта констатації незворотної смерті, тобто смерті його головного мозку або фіксації у медичній документації факту ії біологічної смерті.

Смерть мозку визначається при повному i незворотному припиненні всіх його функцій, що реєструється при працюючому серці і штучній вентиляції легень. Констатація смерті мозку донора здійснюється консиліумом лікарів закладу охорони здоров'я, в якому знаходиться пацієнт, на підставі діагностичних критеріїв смерті мозку людини. За фактом констатації смерті мозку донора консиліум лікарів складає акт, який підписується всіма членами консиліуму та долучається до медичної документації пацієнта. До складу даного консиліуму не можуть бути включені лікарі, які беруть участь у вилученні анатомічних матеріалів та ї трансплантації, а також трансплант-координатор закладу охорони здоров'я. Біологічна смерть людини встановлюється медичним працівником на підставі діагностичних критеріїв біологічної смерті людини (незворотне припинення кровообігу та дихальних функцій, поява ранніх та/або пізніх трупних змін) з внесенням відповідних відомостей до медичної документації пацієнта. У разі встановлення біологічної смерті людини констатація смерті мозку людини не проводиться.

Сумісність органів, тканин або інших анатомічних матеріалів донора та реципієнта. Законом України «Про застосування трансплантації анатомічних матеріалів людині» передбачено створення Єдиної державної інформаційної системи трансплантації органів та тканин та Державної інформа- 
ційної системи трансплантації гемопоетичних стовбурових клітин, до яких вносяться відомості про реципієнтів, а також про осіб, які заявили про свою згоду або незгоду стати донорами.

У разі, коли взятий у донора орган через відсутність біологічно сумісного реципієнта не може бути використано для трансплантації у відповідному медичному закладі, який має ліцензію на надання медичної допомоги із застосуванням трансплантації та/або здійснення діяльності, пов'язаної з трансплантацією, цей заклад негайно надає інформацію про зазначений орган до центрального органу виконавчої влади, що забезпечує формування державної політики у сфері охорони здоров'я, який оперативно здійснює пошук реципієнта в межах України. Якщо біологічно сумісного з отриманим органом реципієнта в межах України не знайдено, центральний орган виконавчої влади, що забезпечує формування державної політики у сфері охорони здоров'я, надає інформацію про цей орган відповідним установам i організаціям інших країн, з якими Україна уклала міжнародні договори з питань трансплантації.

При цьому слід враховувати, що органи, взяті у осіб, можуть передаватися іншим країнам лише на умовах рівноцінного обміну в порядку, визначеному відповідними міжнародними договорами України.

У випадку наявності захворювань у донора, які можуть передатися при трансплантації анатомічних матеріалів людини, така особа не може бути донором. Це, як правило, інфекційні хвороби (СНІД, гепатит), наявність яких у донора 3 впевненістю свідчитиме про їх передачу реципієнту з пересадженим органом, тканиною чи клітиною.

Особи, хворі на інфекційні хвороби, що можуть передаватися через кров, або ін $ф і-$ ковані збудниками таких хвороб, можуть залучатися до виконання донорської функції лише у разі подальшого використання отриманих від них крові та (або) ії компонентів виключно для проведення наукових досліджень, виготовлення діагностикумів та інших продуктів, що не призначаються для введення реципієнтам. Разом з тим, у випадку наявності поінформованої згоди реципієнта трансплантація таких анатомічних матеріалів допускається. При цьому слід враховувати, що така згода повинна бути добровільною та наданою в письмовій формі. Її отриманню передує надання повної та об'єктивної інформації про можливі наслідки для здоров'я реципієнта як безпосередньо після операції, так і у віддаленій перспективі.

Як зазначено вище, для виникнення цивільних правовідносин з донорства необхідна наявність не лише фактів медичного характеру, але і певних юридичних фактів.

Найбільш складним і дискусійним залишається така юридична підстава здійснення донорства, як прижиттєва згода донора (членів сім'ї або близьких родичів, повноваженого представника після його смерті) на вилучення органів за життя і після смерті. Це у свою чергу обумовлює важливість розробки зваженої позиції стосовно критеріїв правомірності здійснення донорства, які розглядувались вище.

Чинне законодавство визначає кілька можливих варіантів поведінки особи, яка виявила бажання стати донором, однак не бажає писати за життя згоду на це. Один з таких варіантів - це призначена за життя уповноваженого представника. Так, кожна повнолітня дієздатна особа має право призначити свого повноважного представника, який після смерті цієї особи надасть згоду на вилучення з їі тіла анатомічних матеріалів для трансплантації та/або виготовлення біоімплантатів. Повноважним представником може бути лише повнолітня дієздатна особа, яка свідомо та добровільно надала згоду.

Письмова заява особи про призначення повноважного представника засвідчується особистими підписами особи, яка призначає повноважного представника, та особи, яка призначається повноважним представником.

Кожна повнолітня дієздатна особа має право у будь-який час подати письмову заяву про відкликання своєї письмової заяви щодо призначення повноважного представника або надати нову письмову заяву про призначення нового повноважного представника. Кожне нове призначення повно- 
важеного представника анульовує статус попереднього повноваженого представника.

Національне законодавство не робить необхідним призначення повноважним представником 3 числа родичів чи членів сім’і. 3 урахуванням викладеного можуть виникати ситуації, коли повноважним представником буде призначена особа, яка незнайома 3 родичами та членами сім'ї покійного. Окрім того, закон також не зобов'язує потенційного донора ставити до відома про таке призначення членів сім'ї чи близьких родичів.

У зв'язку із викладеним вважаємо, що з метою уникнення ситуацій, коли члени сім’і та близькі родичі дізнались про призначення повноважним представником донора сторонньої особи після смерті самого донора, та необгрунтованої підозри у його заінтересованості в отриманні анатомічних матеріалів, така заява, попри іiі письмову форму, повинна бути нотаріально посвідченою. Вказане зведе до мінімального ризик призначення повноважних представників особами, які в силу своїх фізичних чи психічних вад (за відсутності позбавлення дієздатності), не можуть дати усвідомленої згоди на розпорядження своїм тілом після смерті іншій особі.

Часом у правовій науці форми надання згоди на здійснення права на донорство визначаються опосередковано: слід надати особі більше можливостей розпоряджатися своїми органами і тканинами шляхом їхнього відчуження. Як наслідок, особа за життя може не тільки висловлювати згоду або незгоду на використання його органів для трансплантації в разі смерті, а й укласти угоду про використання його анатомічного матеріалу після смерті на певних і прийнятних для нього умовах, заповісти або подарувати орган чи тканину [6, С.40].

Однією 3 основних правових гарантій щодо здійснення чи відмови від здійснення права на донорство після смерті до прийняття Закону України «Про застосування трансплантації анатомічних матеріалів людині» був заповіт, оскільки згода донора на посмертне вилучення анатомічних матеріалів згідно з положеннями Закону України «Про трансплантацію органів та інших анатомічних матеріалів людині», який втратив чинність, не підкріплювалась жодним правовим механізмом.

Діючим Законом України «Про застосування трансплантації анатомічних матеріалів людині» встановлений чітких механізм отримання такої згоди.

Разом із тим, надання такої згоди в правовому полі визнається одностороннім правочином, що виконується після смерті, а це не що інше, як аналогія заповіту [9].

Заповіт - це юридично оформлена воля, для виконання іiі після смерті. Відповідно до статті 1233 ЦК України заповітом є особисте розпорядження фізичної особи на випадок своєї смерті.

В загальних положеннях про спадкування зазначається, що особисті немайнові права не можуть входити до складу спадщини. Вважаємо, зазначені норми, особливо в контексті розглядуваного питання, слід визнати застарілими, і відповідно, вони потребують конкретизації. Також необхідно пам'ятати про принцип свободи заповіту, як один із головних, що полягає у праві заповідача заповісти своє майно або права на власний розсуд, у праві змінити або скасувати свій заповіт в будь-який час.

Про новий інститут приватного права - медичний заповіт у своїй науковій праці вказує Г. І. Миронова. Поняттям «living will» (дослівно - «прижиттєвий заповіт») позначається письмовий документ, в якому повнолітня дієздатна людина заздалегідь висловлює свою волю на випадок ситуацій, в яких вона вже не може говорити за себе. Заповіт є адекватним документом, який містить побажання відносно медичного обслуговування на випадок, коли пацієнт вже не в стані спілкуватися ані з лікарями, ані з родичами. Ці юридичні форми роз'яснюють переваги, типи лікування та догляду, що є бажаними чи небажаними для пацієнта. Документ не тільки гарантує, що переваги та побажання стануть відомі, він також захищає близьких від необхідності приймати важкі рішення та забезпечує медичному персоналу імунітет від правової відповідальності або звинувачень в неетичній і непрофесійній поведінці [5, C.1, 7-8].

Про заповідання своїх органів після смерті в контексті законодавства про до- 


\section{Дискусії, обговорення, актуально}

норство Великобританії згадує Й. Дангата зазначаючи, що чимало донорів, які вирішують віддати свої органи після смерті, ймовірно, включать своє рішення у свій заповіт чи повідомлять про цей намір своїй сім’ї або ж когось, хто виконуватиме їхню волю після смерті. Чимало сімей розглядають виконання цієї частини заповіту покійного як вияв своєї любові та поваги до нього» [2, С.23].

Ще одним аргументом на користь необхідності правового регулювання посмертного донорства на підставі заповіту є прецедент, який стався в США у 1993 році, коли чоловік на Вільям Кейн учинив самогубство. Незадовго до цього він помістив на зберігання у кріобанк свою сперму і заповів ії своїй нареченій Деборі для народження спільної «посмертної» дитини, якщо вона цього побажає. Його дорослі діти проти цього категорично заперечували, однак апеляційний суд Каліфорнії постановив, що вкладники банку сперми можуть самостійно визначати порядок використання своїх репродуктивних клітин після смерті та присудив генетичний матеріал померлого Деборі. [8]

Аналізуючи вказане рішення слід зазначити, що прижиттєво висловлена воля донора має пріоритет по відношенню до думок членів його сім'ї чи близьких осіб.

Згідно положень частини 2 статті 1240 ЦК України заповідач може зобов'язати спадкоємця до вчинення певних дій, спрямованих на досягнення суспільно корисної мети. Таким чином, особа, яка має на меті здійснити право на донорство після смерті, зазначаючи про це в заповіті [3, С.313], не заповідає своє немайнове право, а здійснює його за життя, зобов'язуючи конкретного спадкоємця донести закладу охорони здоров'я згоду на вилучення органів, тканин чи інших анатомічних частин тіла на випадок смерті, таким чином, досягнути суспільно корисної мети.

Окрім того, обмежуватися лише наданням згоди на вилучення донорського матеріалу немає підстав, адже органи, тканини чи інші анатомічні частини організму можуть стати предметом заповіту конкретному закладу охорони здоров'я чи науковій установі за відсутності комерційного елементу [4].
Заповідач самостійно визначає обсяг того, що передається в спадок, він може охопити заповітом права та обов'язки, які йому належать на момент складення заповіту, а також ті, які можуть йому належати у майбутньому, заповідати все майно або його частину. Якщо виходити із норм закону, можна прямо у заповіт, крім пунктів, які стосуються порядку розпорядження належним майном після смерті, внести положення щодо того, висловлюєте ви згоду на участь у донорстві, і чи можуть анатомічні матеріали бути використані у трансплантації, чи така воля висловлена вже раніше. Після засвідчення заповіту складається заява у встановленій формі та спрямовується до відповідних органів виконавчої влади. За цією заявою особа повідомляє, що нею було складено заповіт, зазначається ким і коли він посвідчений, а також те, що, крім майнових питань, до нього внесено питання про згоду, або незгоду на вилучення анатомічних матеріалів з тіла після смерті. Проте, необхідно пам'ятати, що розпорядження щодо згоди або незгоди використання органів та анатомічних матеріалів у програмах донорства $-\epsilon$ розпорядженнями немайнового характеру, і відповідно, слід мати на увазі, що заповіти, які складаються виключно з розпоряджень немайнового характеру, визнаються недійсними.

Таким чином, відповідно до вищевказаного, підставою правовідносин посмертного донорства можна вважати вчинення правочину у формі заповіту. Особа, на випадок смерті може заповісти право надання згоди на вилучення з організму заповідача донорського матеріалу конкретному спадкоємцю або заповісти свої органи та інші анатомічні матеріали визначеному закладу охорони здоров'я або науковій установі.

\section{література}

1. Брюховецька М.С. Загальна характеристика договірного регулювання посмертного донорства. Право і безпека: науковий журнал/Гол. редактор: М.Ю. Бурдін. - Х.: Харківський національний університет внутрішніх справ, 2017. - № 3 (66). - 2017. C. 117-118. 
2. Дангата Й. Гідність у донорстві органів - збалансування інтересів зацікавлених осіб. Медичне право. 2013. № 1 (11). C. 23 .

3. Ільющенкова К.О. Здійснення права на донорство. Наука та практика сучасної юриспруденції: VI всеукраїнська науково-практична конференція (м.Харків, 02.11.2015). Національний юридичний університет ім. Ярослава Мудрого. С. 313.

4. Ільющенкова К. О. «Право на донорство в цивільному праві України» Дисертація Київ - 2018 [Електронний ресурс] режим доступу: http://idpnan.org.ua/files/2018/ ilyushchenkova-k.o.-pravo-na-donorstvo-vtsivilnomu-pravi-ukrayini- a $\cdot$ doc

5. Миронова Г. А. Медичний заповіт: новий інститут приватного права. Часопис Академії адвокатури України. 2012. № 14. C. 1,7-8.

6. Мусієнко А. В. Деякі правові та організаційні проблеми використання трансплантатів. Вісник Академії праці і соціальних відносин Федерації профспілок України. 2002. № 3. С.40.

7. Петруня А., Коваленко Т. Реформування законодавства в галузі трансплантації: медичні та правові аспекти. // Право України: юридичний журнал/Гол. ред.: О.Д. Святоцький. - 7/2013. - Київ: Редак-

\section{SUMMARY}

The article is devoted to the grounds of donation and transplantation in Ukraine. The emergence of civil relations is associated with the emergence of legal facts - various life circumstances that create certain legal consequences. However, not all life circumstances become legal facts. This requires that the rules of civil law link them to certain legal consequences. Legal facts that are the basis for the emergence of civil law in relation to donation, have their own specifics. First of all, the point is that this should not be one legal fact, but a certain set of them. And secondly, such grounds can be divided into two groups: medical and legal.

Keywords: anatomical materials; donation; medical worker; recipient; transplantation.

ція журналу «Право України». - 2013. C. 316 .

8. Свитнев К. Жизнь после смерти. Юридические и этические аспекты посмертной репродукции. [Електронний ресурс]. - Режим доступу: URL: http://svitnev.ru/ speech/life_after_death.pdf (дата звернення: 15.06.2019).

9. Цивільний кодекс України : закон України від 16.01.2003 № 435-IV. Офіційний вісник України. 2003. № 11. Ст. 461. [Електронний ресурс], режим доступу: https:// zakon.rada.gov.ua/laws/show/435-15 